\title{
Fatwa in Islamic Law, Institutional Comparison of Fatwa in Malaysia and Pakistan: The Relevance of Malaysian Fatwa Model for Legal System of Pakistan
}

\section{Muhammad Ifzal Mehmood*}

Department of Law, Faculty of Shariah and Law, International Islamic University, Islamabad, Pakistan

\begin{abstract}
Fatwa is a Muslim religious practice which helps to mould the thoughts and actions for a particular community or person on any special issue, which effects social, economic and personal interest. The institution of fatwa plays a vital role in the contemporary society where different people and different legal regimes exist. It can be utilized as an instrument of social, political and religious control. In Malaysia, a fatwa has been institutionalized and has been used in all spheres of administration and activities related to human endeavor. On the other hand Pakistan is also an Islamic country and its constitution of the country is Islamic. Fatwa in Pakistan is not institutionalized. There are a lot of problems raised in Pakistan and reason is that there is no any Islamic legal institution to administer that issues. There is a need to take Malaysia Fatwa as a model to give legal status and give judiciary the power to implement that Islamic verdict.
\end{abstract}

\section{Keywords: Mufti; Malaysia; Pakistan; legal opinion}

\section{Introduction}

Islamic Republic of Pakistan has been divided into different sects and masalik. Each of them has its own madaris that are producing muftis in a greater number who have authority of issuing fatwa in the light of the traditional rulings of their respective Ammah [1]. Constitutionally, the legislative authority is Parliament whose majority of the members is illiterate and unaware regarding both aspects of the knowledge inter alia modern sciences and Qur'anic sciences. To recognize Shari'ah validity of any law made by the Parliament, Council of Islamic Ideology has been established whose recommendations have no binding force (Constitution of Pakistan, 1973). The third source of legislation is judiciary which has authority to legislate through the process of interpretation. The function of the interpretation has been assigned to the High Courts, Federal Shari'at Court and the Supreme Court of Pakistan. So far as concerned, the task of issuing fatwa in Pakistan, it has been exercising by a great number of muftis. For a correct understanding of the activity of issuing fatwa it is better to have a bird eye view of the historical development of this process.

While on other hand in Malaysia fatwa has been considered as a religious verdict that assists in regulating Muslim conduct of activities in the country. The Federal constitution of Malaysia vested the responsibility for enacting laws in the hand of parliament at the Federal level and the state Assemblies at the state level [2]. Fatwa has been used as an instrument for clarification and coordination of issues in Malaysian Judicial, political and financial sectors. Once it is published in the Gazette, it becomes a binding and enforceable phenomenon in Malaysia [2]. This research cover Malaysia model of fatwa for implementation in Pakistan.

\section{Fatwa in Islamic Law}

The concept of Fatwa is not a new phenomenon in Islamic law. It has enacted from the Quran: whereas Allah has commanded the Muslim faithful who are not knowledgeable in Islam to always seek knowledge from those who possess it. This legal basis has been reiterated by many scholars while tracing the genesis of fatwa in Islam. In fact, most of the Muslims scholars have been capitalizing on the above verse to explain much about the concept of fatwa [3]. The term fatwa (Islamic legal Verdicts) is an Arabic term which is related to some compound words and phrases revealed in the Qur'an such as ifta (issuing Islamic verdict), istefti (request for an Islamic verdict), mufti (a person who issues an Islamic verdicts) and yufti (he issues an Islamic verdict) [3]. In the Qur'an, the almighty Allah has used the terms at several occasions, especially in making reference to the concept of asking questions with a view to providing the responses.

Fatwa according to the English/ Arabic Dictionary is a legal opinion issued by Islamic scholars. In the Oxford Dictionary [4], it has been mentioned that the word fatwa originated from the term "ifta" (to decide a point of law), and it can simply be defined as a ruling on a point of Islamic Law which is to be issued by a recognized authority. Thus the term fatwa could be defined as a formal Islamic legal opinion issued by a jurist- consult ( $m u f t i)$ in response to questions submitted to him by private individuals or judges [5].

\section{Contemporary Situation of Issuing Fatwa in the Muslim World}

The current situation of all over the Muslim world is that the process of ifta' has become a central institution of the Muslim societies to resolve the contemporary issues of the Ummah. Many of the Muslim governments appoint religious scholars on the reserve seats in their legislative bodies. The situations of modern mufti, the public and private, vary from state to state. Some formal institutions of fatwa have been established in many countries, e.g. World Muslim League in Mecca, Fatwa Committee of OIC and the Council of Islamic Ideology in Pakistan. Many specialized committees of muftis are also

*Corresponding author: Muhammad IM, Department of Law, Faculty of Shariah and Law, International Islamic University, Islamabad, Pakistan, Tel: 92-51-9258039; E-mail: ifzaalmehmood@gmail.com

Received July 28, 2015; Accepted August 21, 2015; Published August 26, 2015

Citation: Mehmood MI (2015) Fatwa in Islamic Law, Institutional Comparison of Fatwa in Malaysia and Pakistan: The Relevance of Malaysian Fatwa Model for Legal System of Pakistan. Arts Social Sci J 6: 118. doi:10.4172/2151-6200.1000118

Copyright: () 2015 Mehmood MI. This is an open-access article distributed under the terms of the Creative Commons Attribution License, which permits unrestricted use, distribution, and reproduction in any medium, provided the original author and source are credited. 
working which answer the quarries of the people and provide solution to their contemporary problems, Likewise, Dar al- 'Ulum in India is performing the function of issuing fatwa.

\section{The Concept of Fatwa in Malaysia}

The history of fatwa in Malaysia could not be divorced from discussion on the history of Islamic law in the country. Islamic matters in Malaysia are matters upon which state governments are vested with powers to control, through their respective religious leaders (sultans) and Islamic institutions, However, at the same time the Federal government at the center also established some religious coordinating bodies to oversee and control all the Islamic activities that are going on in the country. Thus, Malaysia Department of Islamic Development "Jabatan Kemajuan Islam Malaysia" (JAKIM) is the main Federal Government agency in Malaysia that is saddled with the responsibility of managing Islamic affairs in the country (JAKIM) [6]. Among its objectives inter alia include: the establishment of an institution that can be responsible for management and coordination of fatwa in the country; and also the coordination of fatwa that can be issued in different states for the purpose of developing the process of collective ijtihad (Ijtihad jami'i) in the country. Broadly, JAKIM serves different roles in Malaysia, among it functions include: to legislate and standardize the Islamic law in Malaysia; to coordinate the Islamic administration in the country; and to adjust and develop the Islamic education in the country (JAKIM) [7]. However, the Department can also perform some specific functions such as serving as the secretariat to the National Council of Islamic Affairs i.e Majlis Kebangsaan Hal Ehwal Islam (MKI) in the country for the purpose of streamlining and implementing the directives and resolutions of the Council of Rulers (Majlis Raja-Raja); serving as an advisory institution to the Federal Government on Islamic matters in general and as well as fatwa matters in particular; streamlining the standardization of Islamic law throughout the country; serving as an Islamic reference center in the country whereby all Islamic affairs are been referred to; enhancing coordination between the various State's fatwa institutions and that of the federal government, thereby developing an effective procedure for harmonizing and standardizing them. Finally, it ensures all the approved fatwa are effectively transmitted and well-disseminated to the larger public.

The manner in which the Islamic activities (such as the issuance of fatwa), are been carried out in various states of Malaysia differs from one state to another [2]. However, one common thing among them all is that, they have almost uniform enactments containing the provisions that regulate the manners and conducts of Islamic affairs in their respective domain. Such enactment is called: "The Administration of Islamic Law enactments" [8]. The enactments provides for the creation of an Islamic Religious Council (Majlis Agama Islam) [9], which is the mother organization that is responsible for advising the Sultan in all matters relating to Islam [9]. Except matters related to Hukum Syarak (Islamic law and administration of justice), of which the enactment has specifically made it as a responsibility for the mufti to advise the Sultan [9]. Furthermore, the Council is also responsible for the promotion of other non-religious matters which are inclined to the development of the economic and socio-political well- being of the Muslim ummah (community) in a state [9].

\section{Practice of Fatwa in Pakistan}

In Pakistan, the task of issuing fatwa has been exercising by a number of religious sects and each of them claims of following its particular maslak in the light of its true teachings. There are unlimited madaris and their graduates are assigned authority to issue fatwa who in fact, are not expertise of Arabic language and their particular madhahb and do not know the methods and the techniques upon which their predecessors had to base during the process of ifta [1]. Majority of them do not know about the flexible and liberal approaches of their Aimmah. For instance, majority of the Pakistani scholars is the follower of Abu Hanifa but only few of them have knowhow about the contextual, flexible and logical approaches of Abu Hanifa and majority of them are deciding the contemporary issues in the light of the literal interpretation of the past juristic opinions of their Imam who elaborated and constructed the legal texts of the Qur' an and the Sunnah (peace be on him) in the light of their contextual meanings, objectives, public interest, customs and his own logical reasoning [1].

Not only is this but there are number of people who do not know the parameters and the subject-matter of fatwa and are issuing fatwa regarding non-issues and are trying to sabotage the true spirit of Shari'ah [10]. This unlimited and unrestricted authority of issuing fatwa in Pakistan has created so many problems for Pakistani people and especially for women. For instance, a fatwa was issued on April 2012 in Kohistan against the women of NGO's that they would be forcefully married to the local men if they dared to enter there. Likewise, on May 11, 2012, in a mosque of Noshki, Baluchistan, a fatwa was issued that any women using a cell phone will have acid thrown on her face [11]. This and similar fatwa not only cause to slander Islamic law but also cause to destruct the flexible structure of Islamic law and its liberal system of interpretation. However, the fatwa issued by a mufti has no legal validity and remains optional to follow until adopted by the court through legal decision. There is Islamic Ideology council made for the recommendation of fatwa. The Council of Islamic Ideology is a constitutional body that advises the legislature whether or not a certain law is repugnant to Islam, namely to the Qur'an and Sunnah (Article 230, Constitution of Pakistan, 1973). This website is designed to provide information about the activities of the Council in this regard. It is updated frequently.

\section{Conclusion}

The concept of fatwa in Malaysia is beyond a mere legal opinion of a mufti. Hence it is binding piece of legislation that attracts a force of law. The fatwa making process in Malaysia is bureaucratized and institutionalized in such a way that any verdict issued and published in the Gazette shale become binding on all Muslims and Shari'ah courts. It has been considered as another form of making legislation in the country but in a delegated manner. Unlike Pakistan which is also Islamic country. There is a council made in the name of Islamic Ideology, its function is to advice the legislature whether or not a law is repugnant to Islam. But their power is limited and there is no any implementation authority in the hand of Islamic Ideology. It is quite necessary that Pakistan should take Malaysia as a model country for the institutionalization of Fatwa.

\section{References}

1. Razi N (2014) Fatwa as a Non-State Legal System: A Critical Analysis from the Perspective of Pakistani Society. Journal of Islamic Studies and Culture 7-18.

2. Chirom M (2014) The concept of Fatwa (Islamic Verdict) in Malaysia and the Constitutional Dilemma: A legislation or Legal Opinion. International Journal of Business and law 11-20

3. Chirom M (2014) Role of Fatwa in the Fight against Terrorism: The Relevance of the Malaysian Fatwa Model to the anti-Boko Haram Crusade. Journal of Law and Social Sciences 34-38. 
Citation: Mehmood MI (2015) Fatwa in Islamic Law, Institutional Comparison of Fatwa in Malaysia and Pakistan: The Relevance of Malaysian Fatwa Model for Legal System of Pakistan. Arts Social Sci J 6: 118. doi:10.4172/2151-6200.1000118

Page 3 of 3

4. Meaning of the word Fatwa in English/Arabic Online Dictionary.

5. Gilani SY, Younas Gilani SM (2011) Jurists and Legislatures in Islam: Origins and clasisification of Ulama, in contemporaty issuesin In Islamic Law. Serial Publication, New Delhi.

6. JAKIM Functions.Department of Islamic Development Malaysia (JAKIM)

7. JAKIM. Vission, Mission, Objectives, Function and Client Charter

8. Bari AA (2003) Malaysian Constitution- A Critical Introduction. Kaualampur, Malaysia.
9. Laws of Malaysia (1993) The Administration of Islamic Law (Federal Territories) Act 505.

10. Abdul Rahman NN, Rahman AA, Karim AA (2012) A Study on StudentsResearch Related to Fatwa submitted at Malaysian Public Universities. International Journal of Humanities and Social Science.

11. The Malaysia Federal Constitution (1988) Two Women appointed as Shari'ah Judges in Malaysia. 